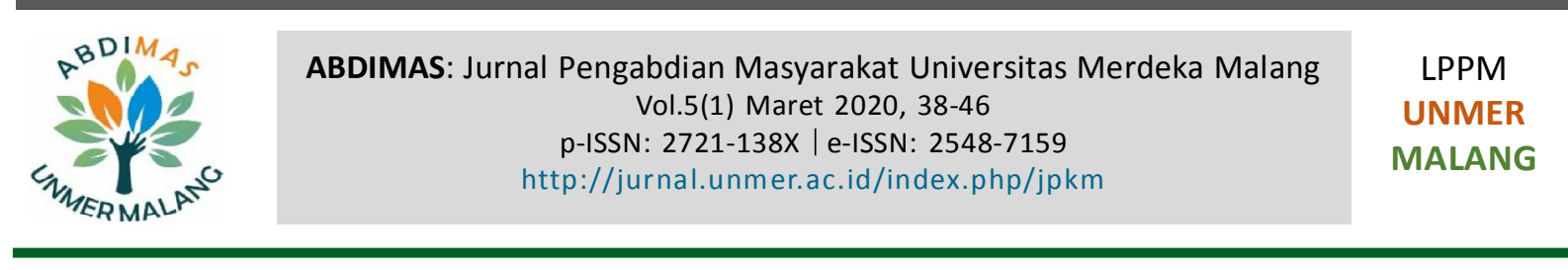

\title{
Penerapan Sistem Informasi Tagihan (SiTagih) untuk Meningkatkan Kinerja Pencatatan Tagihan dan Keuangan
}

\author{
Ahmad Faisol, Mochammad Ibrahim Ashari, Mira Orisa \\ Departemen Teknik Informatika, Fakultas Teknologi Industri \\ Institut Teknologi Nasional Malang, Jl. Raya Karanglo Km.2, Malang, 65145, Indonesia
}

\section{ARTICLE INFO:}

Received: 2019-10-27

Revised: 2019-12-24

Accepted: 2020-02-11

\section{Keywords:}

billing systems; computer applications; freight forwarding services; vb.net

\begin{abstract}
PT Semesta Mitra Sejahtera is a company engaged in the field of public goods transportation services. The existing system is still manual, especially for recording bills, determining the allocation of goods in trucks, and making Bill Notes. To increase efficiency and effectiveness, a new computerized system is needed to accelerate the administration and billing processes that are accurate to the users of transportation services according to the needs of the company owner. The database used is Microsoft Access, while the application is created using the Visual Basic.NET programming language. The results achieved in the form of computer applications that are easy to operate because of its user-friendly appearance. After the application is complete, the service team conducts training for users at PT Semesta Mitra Sejahtera. This training is expected to help partners in mastering the use of applications, especially for recording bills.
\end{abstract}

\footnotetext{
(c) 2020 Published by University of Merdeka Malang. This is an open access article distributed under the CC BY-SA 4.0 license (https://creativecommons.org/licenses/by-sa/4.0/)
}

\begin{abstract}
How to cite: Faisol, A., Ashari, M. I., \& Orisa, M. (2020). Penerapan Sistem Informasi Tagihan (SiTagih) untuk Meningkatkan Kinerja Pencatatan Tagihan dan Keuangan. Abdimas: Jurnal Pengabdian Masyarakat Universitas Merdeka Malang, 5(1), 38-46. https://doi.org/10.26905/abdimas.v5i1.3564
\end{abstract}

\section{PENDAHULUAN}

PT Semesta Mitra Sejahtera (SMS) yang berlokasi di jalan Pandaan-Malang merupakan perusahaan yang bergerak di bidang jasa angkutan barang umum. Perusahaan ini merima pesanan pengiriman barang partai dan paket barang besar dengan rute ke berbagai wilayah di Jawa Timur, Jawa Tengah, dan Jakarta. Setiap perusahaan yang menjadi pelanggan, melakukan pemesanan untuk pengiriman barang ke beberapa wilayah tujuan, dari setiap pesanan tersebut maka muncul tagihan pengiriman barang (delivery order) yang akan ditagih jika barang sudah sampai di tempat tujuan.

Integrasi fasilitas pelayanan masyarakat dalam bentuk inovasi teknologi yang berlaku pada sistem administrasi, information sharing, maupun kolom pengaduan dari warga masyarakat belum dimiliki semua lini (Yudhistiro et al., 2019). Selama ini, proses pencatatan tagihan dan perhitungan laba rugi masih dilakukan 


\section{Penerapan Sistem Informasi Tagihan (SiTagih) untuk Meningkatkan Kinerja... \\ Ahmad Faisol, Mochammad Ibrahim Ashari, Mira Orisa}

dengan aplikasi yang semi manual, yaitu menggunakan Microsoft Excel yang masih dirasa kurang efektif dan efisien. Sistem Informasi berbasis website memungkinkan pelayanan yang efisien dan transparan (Jogiyanto, 2005). Beberapa diantaranya adalah menerbitkan informasi, menyediakan layanan online dan memaksimalkan nilai pelayanan publik, mempercepat proses berbagi sumber daya dan meningkatkan proses pengambilan keputusan, meningkatkan otomasi kantor, dan meningkatkan efisiensi administrative (Yudhistiro et al., 2019). Sistem informasi yang terintegrasi tersebut perlu didukung suatu perangkat lunak yang memadai. Rekayasa perangkat lunak meliputi semua aspek produksi perangkat lunak, mulai dari tahap awal requirement capturing (analisa kebutuhan pengguna), specification (menentukan spesifikasi dari kebutuhan pengguna), desain, coding, testing sampai pemeliharaan sistem setelah digunakan (Ghozali, 2004; Irmayani, 2019).

Berdasarkan keluhan yang disampaikan oleh perusahaan tentang perangkat lunak dengan penggunaan aplikasi, maka sudah selayaknya pengolahan data pada perusahaan dengan armada angkutan yang cukup besar seperti ini dilakukan secara efektif dengan aplikasi yang berbasis data relasional, terintegrasi, dan user friendly sehingga mudah untuk dikelola dan diorganisasi. Sistem Informasi Tagihan (billing system) harus dapat mengintegrasikan beberapa bagian dari divisi yang terlibat dalam memberikan pelayanan (Huang, 2014; Irawan, 2018). Billing system adalah suatu sistem yang dapat membantu para pelaku usaha kecil menengah untuk mengatur dan mencatat segala transaksi yang terjadi, sehingga para pelaku usaha kecil menengah dapat berperan dalam pengembangan industri 4.0 (Saputra et al., 2019).

Permasalahan yang dihadapi mitra adalah: (1) belum ada aplikasi yang terstruktur dalam mengelola tagihan kepada pelanggan. (2) Hanya pemilik yang hafal dengan kode pelanggan dan kode transaksi tagihan, sehingga selama ini pencatatan tagihan dilakukan sendiri oleh pemilik. (3) Kesulitan melakukan rekapitulasi tagihan dan keuangan karena masih menggunakan Microsoft Excel.

Melihat betapa pentingnya kebutuhan terhadap aplikasi pencatatan tagihan dan keuangan tersebut, maka pada pengabdian ini, penulis akan mengembangkan sebuah aplikasi untuk diterapkan pada PT Semesta Mitra Sejahtera dengan menggunakan Visual Basic.NET dan basis data Microsoft Access.

Hasil dari pengabdian ini diharapkan dapat mempermudah pemilik perusahaan terutama dalam pembuatan nota order, pengalokasian barang ke dalam truk, perhitungan tagihan, pendapatan, biaya serta laba rugi perusahaan.

\section{METODE}

Metode pelaksanaan program pada kegiatan pengabdian kepada masyarakat ini terdiri atas 2 tahap, yaitu perencanaan dan pelaksanaan. Tahap perencanaan dilakukan untuk merancang dan mengembangkan aplikasi Sistem Informasi Tagihan (SiTagih), tahap pelaksanaan merupakan kegiatan instalasi aplikasi dan pelatihan bagi pengguna di lingkungan PT SMS.

\section{Tahap Perencanaan}

Untuk tahap perencanaan, kegiatan yang dilakukan dibagi menjadi 5 metode, yaitu: 
ABDIMAS: Jurnal Pengabdian Masyarakat Universitas Merdeka Malang

Volume 5, No 1, Maret 2020: 38-46

\section{Penjadwalan}

Metode penjadwalan ini berfungsi untuk merencanakan dan menyusun jadwal kunjungan ke PT SMS dalam rangka melakukan wawancara dan observasi. Jadwal disusun dengan melakukan penyesuaian antar setiap personil, jangan sampai ada jadwal yang bentrok dengan kegiatan lain.

\section{Wawancara dan observasi}

Metode wawancara digunakan untuk mengumpulkan data tentang alur proses kerja pencatatan tagihan pada PT SMS. Wawancara dilakukan dengan direktur dan sekretaris PT SMS.

Metode observasi digunakan untuk melakukan pengamatan secara langsung terhadap proses pencatatan tagihan dan keuangan pada PT SMS. Hal ini bertujuan untuk mensinkronkan antara hasil wawancara dengan kenyataan yang terjadi di lapangan, sehingga dapat ditemukan titik - titik permasalahan yang selama ini dikeluhkan oleh PT SMS.

\section{Analisis dan desain}

Berdasarkan data yang diperoleh dari hasil wawancara dan observasi di lapangan, dilakukan proses analisis untuk menemukan solusi pemecahan masalah terbaik. Hasil dari analisis berupa dokumen persyaratan dan kebutuhan sistem yang akan dikembangkan, seperti kebutuhan fungsional dan kebutuhan non fungsional.

Dokumen hasil analisis tersebut kemudian digunakan untuk melakukan perancangan aplikasi, seperti perancangan alur data dan sistem, desain antarmuka, serta desain basis data.

\section{Implementasi sistem}

Hasil dari analisis dan desain, digunakan untuk memulai proses implementasi sistem atau proses pengkodean pengembangan aplikasi. Sesuai permintaan dari PT SMS bahwa aplikasi harus berbasis desktop, maka bahasa pemrograman yang digunakan adalah Visual Basic dengan menggunakan perangkat editor dan kompiler Visual Studio.Net (Troelsen, 2002; Yuswanto \& Subari, 2007). Sedangkan implementasi basis data menggunakan salah satu produk dari Microsoft Office, yaitu Microsoft Access.

\section{Pengujian unit dan sistem}

Pengujian unit digunakan untuk memvalidasi setiap fungsi dan fitur pada aplikasi. Sedangkan pengujian sistem digunakan untuk memvalidasi alur kerja dari sistem secara keseluruhan, apakah input sesuai dengan output berdasarkan hasil analisis.

\section{Tahap Pelaksanaan}

Tahap pelaksanaan dilakukan setelah proses pengembangan aplikasi selesai, yang dilanjutkan dengan melakukan instalasi pada perangkat komputer di PT SMS. Proses pelatihan terhadap pengguna dilakukan setelah aplikasi dinyatakan siap. Tahap pelatihan diikuti oleh pimpinan dan sekretaris PT SMS yang nantinya menjadi pengguna aplikasi. Pada tahap akhir ini, peserta dalam hal ini calon pengguna diedukasi bagaimana mengakses aplikasi, melakukan input dan kelola data pelanggan, pengkodean transaksi dan penentuan tarif armada, input dan kelola data armada dan sopir, serta proses pencatatan tagihan dan mencetak nota tagihan maupun laporan bulanan. 


\section{Penerapan Sistem Informasi Tagihan (SiTagih) untuk Meningkatkan Kinerja...}

Ahmad Faisol, Mochammad Ibrahim Ashari, Mira Orisa

\section{HASIL DAN PEMBAHASAN}

Kegiatan pengabdian kepada masyarakat dengan tema penerapan Sistem Informasi Tagihan (SiTagih) untuk meningkatkan kinerja pencatatan tagihan dan keuangan di PT Semesta Mitra Sejahtera (SMS) dilaksanakan pada hari Sabtu 12 Oktober 2019 pukul 13.00 - 16.00 di ruang rapat PT SMS, Pandaan Pasuruan. Bentuk kegiatan adalah pelatihan kepada calon pengguna yang dibagi menjadi 4 sesi. Sesi pertama dilaksanakan pukul 13.00-13.30 yaitu instalasi aplikasi, sesi kedua dilaksanakan pada pukul 13.30 - 14.30 pelatihan input data - data utama atau data master. Sesi kedua dilaksanakan pukul 14.3015.30 adalah pelatihan input data transaksi tagihan dan cetak laporan. Sedangan sesi terakhir adalah penutupan.

Pada sesi pertama, pelatihan yang dilakukan adalah cara instalasi atau pemasangan aplikasi SiTagih pada komputer kantor. Pada sesi ini juga dijelaskan persyaratan-persyaratan perangkat yang harus dipenuhi untuk menginstal aplikasi.

Pada sesi kedua, terdapat beberapa modul aplikasi yang dibahas dalam pelatihan, antara lain modul kelola data kota, modul kelola data wilayah, modul kelola data peternak, modul kelola data angkutan, dan kelola data sopir, seperti yang dapat dilihat pada Gambar $1-5$.

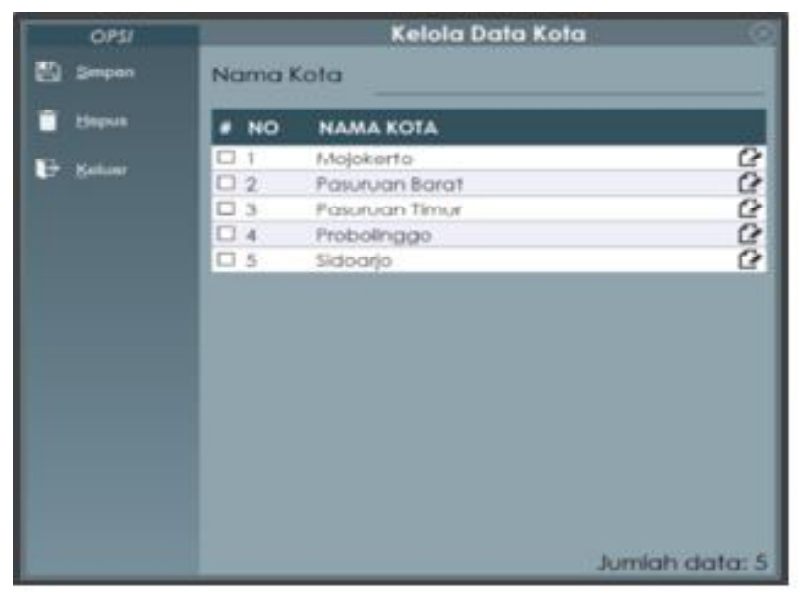

Gambar 1. Form kelola data kota

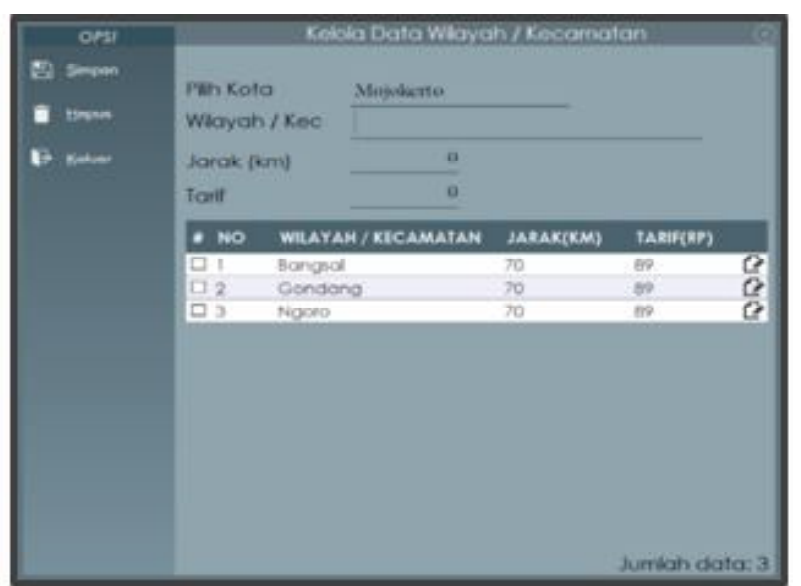

Gambar 2. Form kelola data wilayah

Gambar 1 menunjukkan tampilan form kelola data kota, formulir ini berfungsi untuk mengelola data kota yang menjadi cakupan bagi armada PT SMS dalam mengirimkan barang. Dimana, kota tersebut adalah kota lokasi pelanggan atau Peternak yang akan menerima barang kiriman berupa pakan ternak.

Gambar 2 berhubungan dengan Gambar 1 yang berfungsi untuk mengelola data wilayah cakupan pengiriman sesuai dengan lokasi dimana pelanggan berada. Pada formulir inilah, tarif angkutan ditentukan berdasarkan jarak per kilometer. Penentuan tarif untuk sementara masih bersifat manual, berdasarkan aturan yang sudah ditetapkan oleh PT SMS, jadi aplikasi hanya merekam tarif yang sudah ditentukan sebelumnya. 
ABDIMAS: Jurnal Pengabdian Masyarakat Universitas Merdeka Malang

Volume 5, No 1, Maret 2020: 38-46

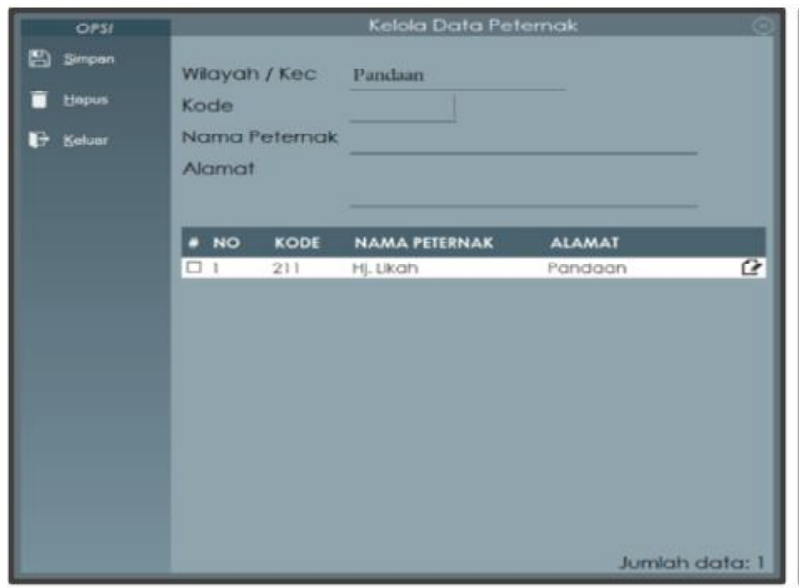

Gambar 4. Form kelola data mobil angkutan

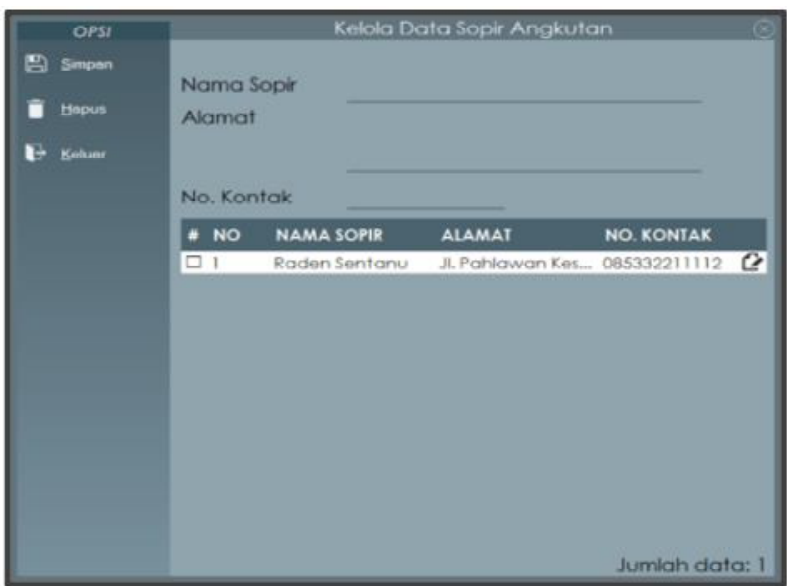

Gambar 3. Form kelola data peternak

Gambar 3 menunjukkan modul untuk mengelola data pelanggan atau peternak yang menjadi tujuan pengiriman barang bagi PT SMS. Pada formulir ini, setiap peternak akan diberikan kode sesuai ketentuan yang telah ditetapkan oleh PT SMS, serta harus dilengkapi nama dan alamat dari peternak. Data peternak dimasukkan berdasarkan cakupan wilayah/kecamatan tempat asal.

Gambar 4 menunjukkan modul formulir data sopir mobil angkutan. Formulir ini berfungsi untuk merekam data sopir yang akan diberi tugas untuk mengendarai mobil angkutan, yang harus dilengkapi dengan nama sopir, alamat, dan nomor kontak (Handphone).

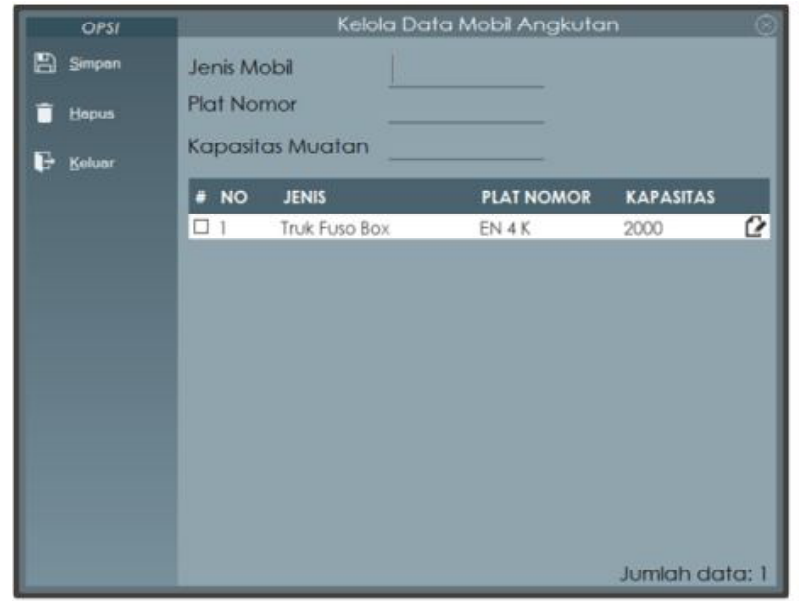

Gambar 5. Form kelola data mobil angkutan

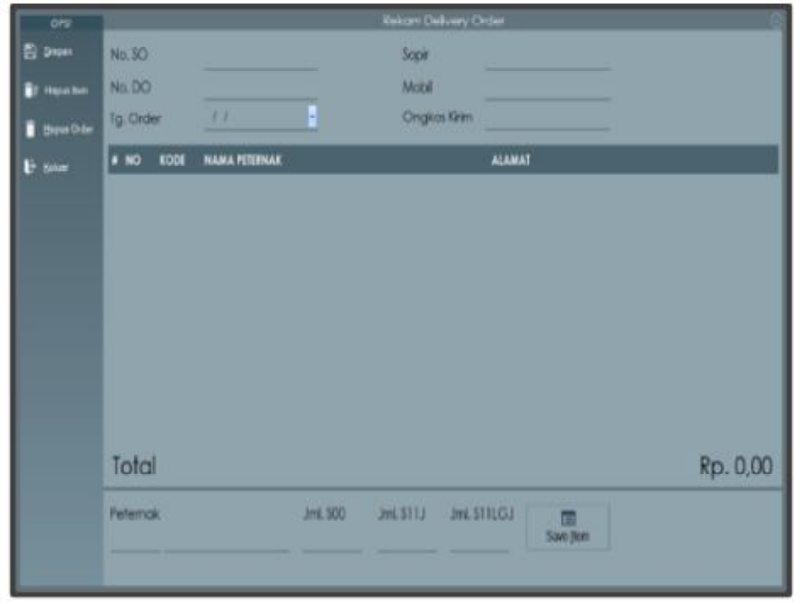

Gambar 6. Form kelola data mobil angkutan

Sedangkan Gambar 5 menunjukkan aplikasi formulir untuk merekam data mobil angkutan atau armada di PT SMS. Pada formulir ini data yang harus dilengkapi adalah jenis dari mobil angkutan (misalkan Truk Fuso), plat nomor kendaraan, dan kapasitas muatan dalam satuan kilogram.

Pada sesi ketiga, bahan pelatihan adalah bagaimana merekam data tagihan serta mencetak hasilnya, seperti yang terlihat pada Gambar 6. 


\section{Penerapan Sistem Informasi Tagihan (SiTagih) untuk Meningkatkan Kinerja... \\ Ahmad Faisol, Mochammad Ibrahim Ashari, Mira Orisa}

Pada proses pencatatan tagihan, terdapat beberapa data yang harus dilengkapi antara lain Nomor Sales Order dan Delivery Order yang diperoleh dari pabrik (Produsen) pakan ternak yang akan mengirim barang ke peternak. Kemudian lengkapi juga tanggal order, sopir dan mobil angkutan yang akan mengirim barang, serta ongkos kirim barang. Setelah semua data utama transaksi terisi, masukkan daftar peternak yang akan menerima kiriman barang atau pakan ternak dari pabrik. Total biaya tagihan akan ditampilkan sesuai berat barang yang dikirim dikalikan tarif angkutan yang sebelumnya telah telah ditentukan pada Form data Wilayah.

Setelah data transaksi terisi secara lengkap sesuai nota order dari pabrik, langkah selanjutnya adalah menekan tombol "Save Item" untuk melakukan penyimpanan data tagihan. Setelah transaksi disimpan, nota laporan dapat langsung dicetak melalui printer.

Sesi keempat adalah sesi penutupan penutupan acara. Bentuk penerapannya berupa sesi perpisahan pihak tim instruktur dengan peserta yang dilangsungkan di Ruang Rapat PT SMS di Kota Pandaan, Pasuruan, Indonesia.

Tabel 1. Jadwal pertemuan kegiatan pelatihan

\begin{tabular}{|c|c|}
\hline \multicolumn{2}{|l|}{ Sesi 1} \\
\hline Aktifitas & - Penjelasan metode pelaksanaan \\
\hline & - Pengenalan peralatan yang akan digunakan \\
\hline & - Pengenalan persyaratan aplikasi yang harus terpenuhi untuk melakukan instalasi \\
\hline & - Pengenalan cara instalasi pada komputer berbasis Windows \\
\hline Tujuan & $\begin{array}{l}\text { - Mengenalkan metode pelaksanaan program pengabdian dan pengenalan kelompok (tim } \\
\text { pelaksana). }\end{array}$ \\
\hline & $\begin{array}{l}\text { - Memberikan pengenalan peralatan dan persyaratan minimal yang digunakan dalam pelaksanaan } \\
\text { program pengabdian. }\end{array}$ \\
\hline \multicolumn{2}{|r|}{ 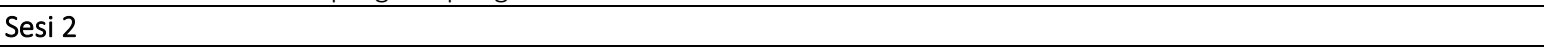 } \\
\hline Aktifitas & - Pelatihan modul kelola data Kota \\
\hline & - Pelatihan modul kelola data Wilayah / Kecamatan \\
\hline & - Pelatihan modul kelola data Peternak / Pelanggan \\
\hline & - Pelatihan modul kelola data Sopir Angkutan \\
\hline & - Pelatihan modul kelola data Mobil / Armada Angkutan \\
\hline Tujuan & $\begin{array}{l}\text { - Untuk dapat memberikan pengetahuan kepada peserta mengenai cara mengelola data - data } \\
\text { utama yang harus diinputkan pada aplikasi. }\end{array}$ \\
\hline \multicolumn{2}{|r|}{ ( } \\
\hline Aktifitas & $\begin{array}{l}\text { - Pelatihan proses perekaman tagihan setiap transasksi pengiriman barang } \\
\text { - Pelatihan cara mencetak nota tagihan }\end{array}$ \\
\hline Tujuan & $\begin{array}{l}\text { - Untuk memberikan pengetahuan mengenai proses pencatatan atau perekaman data tagihan } \\
\text { pada aplikasi serta mencetak nota tagihan. }\end{array}$ \\
\hline \multicolumn{2}{|r|}{ ( } \\
\hline Aktifitas & $\begin{array}{l}\text { - Memberikan kata penutup dan ucapan terima kasih kepada peserta pada pertemuan terakhir } \\
\text { - Membagikan kenang-kenangan kepada peserta } \\
\text { - } \text { Review hasil produk } \\
\text { - Pembacaan do'a } \\
\text { - Penutup. }\end{array}$ \\
\hline Tujuan & $\begin{array}{l}\text { - Untuk memberikan salam perpisahan ucapan terima kasih kepada peserta dan pihak mitra dan } \\
\text { menunjukkan hasil dari pelaksanaan program pengabdian kepada masyarakat. } \\
\text { - Review hasil produk yang telah dibuat oleh peserta yang disertakan acara penutup dari } \\
\text { pelaksanaan kegiatan. }\end{array}$ \\
\hline
\end{tabular}


ABDIMAS: Jurnal Pengabdian Masyarakat Universitas Merdeka Malang

Volume 5, No 1, Maret 2020: 38-46

\section{Relevansi bagi peserta}

Kegiatan program pengabdian pada masyarakat dengan tema penerapan Sistem Informasi Tagihan (SiTagih) pada PT Semesta Mitra Sejahtera (SMS) ini memiliki relevansi dengan kebutuhan bidang usaha yang ada pata PT SMS, yaitu bidang angkutan barang. Dimana, setiap transaksi selalu menghasilkan data tagihan yang selama ini proses pencatatannya masih dilakukan dengan menggunakan aplikasi Microsoft Excel. Pada pelaksanaan program pengabdian berupa penerapan aplikasi dan pelatihan ini, bertujuan untuk menambah pengetahuan peserta mengenai penguasaan dan penerapan suatu pengetahuan dalam hal penerapan sistem informasi pada perusahaan untuk meningkatkan pelayanan pada terutama proses pengelolaan tagihan dan laporan keuangan.

\section{Hasil pelatihan}

Berdasarkan dari hasil wawancara tidak terstruktur antara tim pelaksana dan peserta pelatihan yang disertakan dengan pengamatan langsung selama kegiatan, maka pelaksanaan kegiatan program pengabdian kepada masyarakat oleh tim pelaksana dari Institut Teknologi Nasional Malang memberikan dampak positif seperti yang dapat dilihat pada Tabel 2.

Tabel 2. Perubahan yang terjadi pada khalayak sasaran

\begin{tabular}{|c|c|c|}
\hline Jenis Perubahan & Sebelum Abdimas & Setelah Abdimas \\
\hline $\begin{array}{l}\text { Mengelola data utama (kota, } \\
\text { wilayah \& tarif, peternak, sopir, } \\
\text { angkutan) }\end{array}$ & $\begin{array}{l}\text { Semua data direkam ke dalam MS. Excel, } \\
\text { dimana setiap ada pergantian tahun } \\
\text { atau periode maka harus merekam } \\
\text { ulang, terkadang pengguna harus } \\
\text { menghafal kode peternak dan tarifnya. }\end{array}$ & $\begin{array}{l}\text { Aplikasi sudah menggunakan database } \\
\text { untuk perekaman data, sehingga peng- } \\
\text { guna lebih diberikan kemudahan, tidak } \\
\text { perlu lagi menghafal kode - kode karena } \\
\text { pada saat dibutuhkan tinggal memilih data } \\
\text { pada form aplikasi. }\end{array}$ \\
\hline Pencatatan tagihan & $\begin{array}{l}\text { Melakukan input tagihan dalam berkas } \\
\text { MS. Excel dengan harus menghafal kode } \\
\text { peternak, dan ketika berganti periode, } \\
\text { maka tabel tagihan tersebut harus } \\
\text { disalin pada sheet lain }\end{array}$ & $\begin{array}{l}\text { Proses perekaman tagihan lebih cepat dan } \\
\text { efektif karena tinggal memilih peternak } \\
\text { (penyewa) dan input jumlah muatan, } \\
\text { maka tagihan akan dihitung secara } \\
\text { otomatis oleh aplikasi. }\end{array}$ \\
\hline Cetak laporan & $\begin{array}{l}\text { Cetak laporan berdasarkan hasil rekap } \\
\text { dari beberapa data pada transaksi yang } \\
\text { sudah direkam dalam berkas MS. Excel } \\
\text { sehingga sering terjadi kesalahan } \\
\text { bahkan membutuhkan waktu yang } \\
\text { relatif lama. }\end{array}$ & $\begin{array}{l}\text { Pengguna hanya tinggal mengakses menu } \\
\text { laporan dan memilih periode pelaporan, } \\
\text { sistem akan melakukan rekapitulasi dan } \\
\text { bisa langsung dicetak maupun disimpan ke } \\
\text { dalam berkas dengan format pdf. }\end{array}$ \\
\hline
\end{tabular}

\section{Faktor pendukung}

Dalam pelaksanaan program pengabdian pada masyarakat ini terdapat beberapa faktor yang mendukung terlaksananya kegiatan pengabdian pada masyarakat ini yaitu: (1)Adanya bantuan yang dilakukan oleh pihak PT SMS dalam memberikan fasilitas berupa tempat pelaksanaan serta mensukseskan program pengabdian pada masyarakat dalam bentuk pelatihan ini. (2) Tidak adanya aktifitas lain yang mengganggu dari berlangsungnya program pengabdian pada masyarakat ini. Hal ini dikarenakan dalam prosesnya, program pengabdian ini telah dijadwalkan sebelumnya dengan menentukan waktu yang benar - benar tidak 


\section{Penerapan Sistem Informasi Tagihan (SiTagih) untuk Meningkatkan Kinerja... \\ Ahmad Faisol, Mochammad Ibrahim Ashari, Mira Orisa}

ada kegiatan di antara kedua belah pihak. (3) Adanya kesediaan konsumsi yang disediakan oleh PT SMS pada saat pelaksanaan program pengabdian pada masyarakat, tim pelaksana tidak perlu mengeluarkan biaya lebih untuk mendapatkan konsumsi.

\section{Faktor penghambat}

Dalam pelaksanaan program pengabdian pada masyarakat ini terdapat beberapa faktor penghambat yang terjadi pada saat pelaksanaan aktiftas yaitu (1) Karena aplikasi yang digunakan berbasis.NET Framework, sehingga peserta harus menyediakan perangkat dengan sistem operasi Windows yang benar benar up to date untuk bisa melakukan instalasi aplikasi. Sehingga pada prosesnya, membutuhkan waktu yang lumayan lama untuk melakukan persiapan instalasi karena harus mengunduh aplikasi pendukung yang terbaru, dimana waktu yang dibutuhkan tergantung dari kecepatan koneksi internet dan besarnya ukuran file update. (2) Karena kesibukan dari setiap anggota tim pelaksana dan perwakilan dari peserta, kami kesulitan dalam mengatur jadwal pelatihan, sehingga pelatihan ini bisa dikatakan mundur dari target awal yang telah ditentukan.

\section{SIMPULAN DAN SARAN}

\section{Simpulan}

Dari kegiatan Pengabdian kepada Masyarakat yang telah dilaksanakan dapat diambil kesimpulan Bahwa pengguna aplikasi di PT. Semesta Mitra Sejahtera telah mampu mengoperasikan aplikasi SiTagih dengan baik karena kemudahan pada aplikasi yang user-friendly dan penerapan Aplikasi SiTagih pada PT. Semesta Mitra Sejahtera dapat membantu dan meningkatkan kinerja dalam pencatatan tagihan dan keuangan, khususnya pada proses pencatatan tagihan yang dapat dilakukan dengan lebih cepat dan efisien tanpa harus mengingat atau menghafal kode peternak.

\section{Saran}

Perlu adanya pengembangan fitur yang lebih lengkap pada aplikasi SiTagih untuk mendukung kinerja pada PT SMS, seperti fitur akuntansi, cetak laporan nota surat jalan, dan beberapa fitur lainnya. Selain itu, aplikasi Sistem Informasi Tagihan ini juga dapat dirubah menjadi aplikasi berbasis web, sehingga dapat diakses dari manapun terutama ketika berada di luar kantor.

\section{DAFTAR PUSTAKA}

Ghozali, K. (2004). Rekayasa resiko pengembangan perangkat lunak. JUTI: Jurnal IImiah Teknologi Informasi, 3(2), 76. https://doi.org/10.12962/j24068535.v3i2.a259

Huang, Y. (2014). Central billing system for personal bills. International Journal of Innovation, Management and Technology, 5(4), 323-326. https://doi.org/10.7763/ijimt.2014.v5.534

Irawan, I. (2018). Pengembangan sistem informasi tagihan (billing system) pasien rawat inap pada Rumah Sakit Umum Daerah Bangkinang Kampar. Riau Journal of Computer Science, $4(2), 31-40$. 
ABDIMAS: Jurnal Pengabdian Masyarakat Universitas Merdeka Malang Volume 5, No 1, Maret 2020: 38-46

Irmayani, D. (2019). Rekayasa perangkat lunak. Jurnal Informatika, 2(3), 1-9. https://doi.org/10.36987/informatika.v2i3.201

Jogiyanto, H. M. (2005). Analisis dan Desain Sistem Informasi: Pendekatan Terstruktur Teori dan Praktik Aplikasi Bisnis. Yogyakarta: Andi.

Murtopo, A. A., \& Angesti, D. C (2017). Sistem informasi pelayanan tagihan rekening dan pengaduan pelanggan berbasis SMS Gateway di PDAM Kota Tegal. Jurnal SIMETRIS, 8(2), 457-468. https://doi.org/10.24176/simet.v8i2.1230

Saputra, Z. R., Ismail, T., Maulana, H., \& Pratama, H. (2019). Perancangan sistem billing playstation berbasis Arduino-based Playstation Billing System Design. Jusikom: Jurnal Sistem Komputer Musirawas, 4(02), 59-64. https://doi.org/10.32767/jusikom.v4i2.573

Troelsen, A. (2002). Visual Basic.NET and the.NET Platform: An Advanced Guide. https://doi.org/10.1007/978-1-4302-0849-5

Yudhistiro, K., Sonalitha, E., Rosyadi, H. E., \& Pratama, A. H. (2019). Pembentukan kelompok informasi masyarakat Kelurahan Gadingkasri Kota Malang. JMM-Jurnal Masyarakat Merdeka, 2(2), 14-19.

Yuswanto \& Subari. (2007). Pemrograman Database Visual Basic.NET. Jakarta: Prestasi Pustaka 